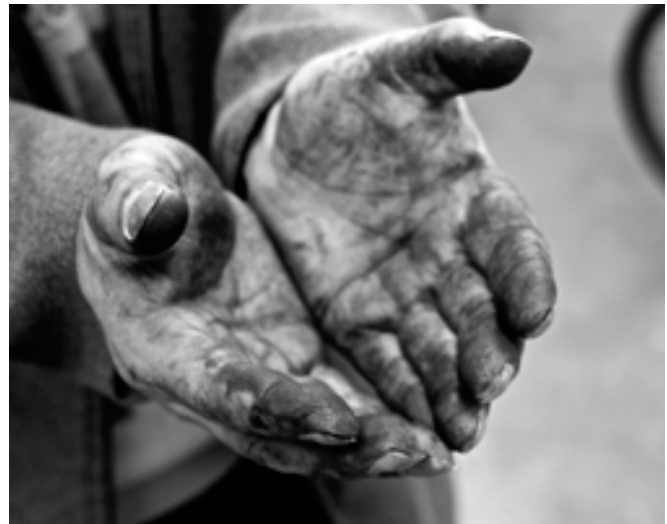

'A worker's soul"

PC: Esmee Van

Heesewijk, @flickr.com

\section{My Rights Have Been Left behind in Papua New Guinea \\ The Predicament of Chinese Overseas Workers}

\section{Shuchi Zhang}

Increasing numbers of Chinese companies are sending employees abroad as part of China's global push. Still, Chinese workers abroad often find themselves vulnerable. By tracking the case of one employee in a Chinese enterprise in Papua New Guinea, this essay reveals the plight of China's relatively powerless overseas workers, an image that stands in stark contrast to the widespread depiction of an increasingly assertive and powerful Chinese global presence.
'Mr Dong [pseudonym] is one of the external hires for our project in Papua

New Guinea (PNG) ... he does onsite surveying. Natives in PNG were outraged at their vehicles getting stuck in the soft soil embankments. Convinced that these

roads were dysfunctional, they hit him with sticks without any forewarning ... in fact, he had nothing to do with such road conditions.

One of Mr Dong's supervisors

'Medical examinations show the dislocation of the first joint connecting my head with the cervical vertebrae; surgery

is the only treatment for this ... I suffer from severe headaches after walking for a while, and cannot lift anything, nothing at all; if I am lifting something I have to stop walking, and must sit down once my headache hits.'

Mr Dong

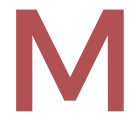
r Dong, a Chinese overseas worker born in the late 1980 s, is employed in PNG-over 6,200 kilometres away from his hometown in Northwest China. The brutal incident that occurred in PNG in May 2014 entangled him in a legal limbo in the Chinese court system that only came to a tentative conclusion four years later, when the First Intermediate People's Court of Beijing delivered its judgement of second instance. With increasing numbers of Chinese companies sending workers abroad as part of China's global push, this case has much to tell us about the increasingly globalised Chinese legal labour regime. It also reveals the plight of China's relatively powerless 
overseas workers, an image that stands in stark contrast to the widespread depiction of an increasingly assertive and powerful Chinese global presence.

\section{A Legal Odyssey}

From a legal perspective, the crux of the dispute in $\mathrm{Mr}$ Dong's case-just as in most legal cases involving work-related injurieslies in the determination of labour relations. Who was responsible for compensating him due to his injury? In April 2013, Mr Dong started working for China Overseas Papua New Guinea Corporation (zhong haiwai baxin gongsi, hereafter COPNGC)-a wholly-owned subsidiary of China Overseas Engineering Group Corporation Ltd. (zhong haiwai gongcheng zeren youxian gongsi, hereafter COEGC Ltd.)-and was dispatched to PNG to work as a surveyor on the Mendi-Kandep Highway project. Fortunately for him, compared to the common practice of sending workers overseas under murky terms of employment that do not provide legal resource to workers, the central state-owned enterprise followed formal recruitment procedures and Mr Dong signed a written employment contract. The legal loophole, however, was that the company signed the contract in their capacity as an overseas-registered independent legal entity, thus creating a jurisdictional problem. Both signatories to the employment contract agreed that the company would purchase personal accident insurance worth 500,000 yuan for $\mathrm{Mr}$ Dong while he was abroad.

The Regulations on Insurance against Workrelated Injuries issued in December 2010 stipulate that enterprises within China must insure all their staff members against workrelated injuries, and that in the absence of such insurance, enterprises shall compensate injured employees in accordance with the coverage and standards specified in the workrelated injury insurance. But it is not clear which firm was directly responsible for $\mathrm{Mr}$
Dong's employment: the state-owned firm or its foreign-owned subsidiary. For example, neither enterprise had contributed to his social security, which was still linked to his previous employer. Given that COPNGC was foreignowned, Mr Dong had to prove that COEGC Ltd. was his actual employer in order to be eligible for insurance compensation in China for workrelated injuries.

Mr Dong sought legal assistance from Beijing Yilian Legal Aid and Research Centre of Labour (Beijing yilian laodongfa yuanzhu yu yanjiu zhongxin), an NGO providing professional legal support related to labour laws [disclosure: the author of this essay is Director of Research at Beijing Yilian]. With its Deputy Director Han Shichun and Lawyer Liu Wei as his attorneys, Mr Dong applied for labour arbitration in 2015 but his request was rejected because COPNGC was the signatory to his employment contract. The Chinese Labour Law stipulates that plaintiffs can take further legal action if they object to labour arbitration decisions that serve as procedural prerequisites. So, in September $2015 \mathrm{Mr}$ Dong and his legal team prepared additional evidence and supporting materials and litigated a second time, continuing to request the determination of the labour relation.

A key point of Mr Dong's case was based on an understanding of the Regulations on Management of Foreign Labour Service Cooperation issued by the State Council in 2012. According to these Regulations, foreign enterprises, institutions, or individuals are not permitted to recruit workers within China who will be sent to work overseas. Being a foreign-owned enterprise, COPNGC is not eligible to directly establish labour relations with Chinese workers within China. During the trial, his attorneys argued that Mr Dong's employment contract with the foreign-owned enterprise violated this rule and should, hence, be deemed void. This would prove the existence a factual labour relation between him and COEGC Ltd. As a second prong of argumentation, the attorneys also pointed out that the Administrative Regulations on 
Contracting Foreign Projects issued in July 2008 by the State Council clearly states that firms contracting foreign projects must not subcontract their projects to other companies with no commensurate qualifications. In other words, COEGC Ltd. must be responsible for subcontracting to COPNGC and is, by extension, responsible for the project on which Mr Dong worked in PNG.

The judgements of first instance and second instance, delivered respectively in January 2018 and May 2018, both supported $\mathrm{Mr}$ Dong's argument, ruling that labour relations existed between COEGC Ltd. and Mr Dong. In addition, in the verdict of second instance the court emphasised that the Administrative Regulations on Contracting Foreign Projects demand that firms purchase overseas personal accident insurance for dispatched workers, and that evidence showed that Mr Dong's commercial insurance policy was paid for by COEGC Ltd., further substantiating the claim that COEGC Ltd. was indeed Mr Dong's employer.

Determining labour relations was a comparatively easy process; but lengthier and more complicated procedures awaited $\mathrm{Mr}$ Dong, including the identification of his workrelated injuries, the assessment of his work capacity, and the request for compensation from his employer.

\section{A Blow to the Neck}

In the popular imagination, on travel websites and guidebooks, PNG is exoticised as a place of spellbinding beauty and native traditions. The reality, however, is more complicated. In a recent country guide published by the Chinese government, the country is described as a place marked by conflict, unemployment, and a lack of infrastructure (Department of Outward Investment and Economic Cooperation 2017).

Obviously, $\mathrm{Mr}$ Dong and his co-workers were dispatched to the real PNG and not the one of the touristic imagination. PNG imposes stringent constraints on visas for foreign workers because of high domestic unemployment rates, and designates China as a 'high-risk' country (Department of Outward Investment and Economic Cooperation 2017). By the end of 2016, there were merely 1,069 Chinese dispatched workers in PNG. The conditions for this small cohort are rather dismal. Ordinary workers dispatched to PNG are entirely segregated from local communities in their daily lives. When problems arise, they lack access to the local institutions and resources that could safeguard their rights and interests. Furthermore, the local minimum wages, average wages, social security, and other benefits they receive in the PNG are significantly inferior to those in their home country. They also face a local workforce that is largely underpaid and therefore often hostile. Monthly wages for local workers approximate 800 kina, the equivalent of 1,574 yuan based on the current exchange rate, and earnings for technicians average 1,200 kina. The National Employment Law in PNG requires employers to purchase social insurance for employees, but a local labour aid agency has yet to be established.

China's Regulation on Work-related Injury Insurance stipulates that Chinese workers dispatched overseas should first join workrelated injury insurance schemes in their host countries while suspending their work-related injury insurance schemes in China. Only when local insurance schemes are unavailable are they entitled to retain their Chinese insurance. But insurance is no trivial matter, especially given the poor medical conditions in host countries and the difficulties involved in seeking compensation from overseas employers. Most workers fall under the management of cooperative enterprises contracting out labour services, and not state-owned enterprises carrying out their own projects. Comparatively speaking, Mr Dong's situation was favourable because he was actually employed by the company he worked for. 


\section{Exporting Labour and its Discontents}

While extreme, the situation facing Chinese workers in PNG is far from unique. As of 2016, 4,394 central state-owned enterprises had established businesses overseas. In 2016, China's outward foreign direct investment flows and stock accounted for 13.5 percent and 5.2 percent, respectively, of the global totals, and the volume of China's outward investment flows ranked second highest among all the countries (regions) worldwide (Ministry of Commerce, National Bureau of Statistics, and State Administration of Foreign Exchange 2016; UNCTAD 2017).

Increasing rapidly alongside outward foreign direct investment are the numbers and economic contributions of overseas workers. By 2017, the number of overseas workers from China totalled 10.1 million, ranking fourth worldwide after India, Mexico, and Russia (World Bank 2017). Annual remittances from Chinese overseas workers amounted to 64 billion USD. Globally, this was second only to the 69 billion USD remitted to India. At the national level, China's unsound domestic legal institutions and its inactive participation in international labour laws and mechanisms have resulted in weak protections for the rights and interests of its overseas workers; incidents at workplaces and attacks from local communities are frequent occurrences for Chinese workers.

Traditionally, workers from countries that export capital on a large scale because of their long-term capital accumulation take up professions and positions with added value. This added value tends to increase as these countries upgrade their industries and strengthen their education and social security systems. This is not the case with regard to China, however. Statistics published a few years ago show that over 80 percent of Chinese overseas workers were still employed in labourintensive industries, such as construction, textiles, and fishing (Fan and Yin, 2013, 340).

\section{A Subordinate Vanguard of a New Globalisation}

The story related above illustrates the contrast between the legal protections and treatment of foreign workers in China, and the dismal conditions that Chinese workers have to endure overseas, often without recourse to legal protections either at home or abroad. They fall, as it were, through the cracks, and are subjected to the full brunt of the systemic risks of globalisation. While China's perceived status as a global power continues to grow, Chinese overseas workers remain subordinate and relatively powerless, even as they play a crucial role in the global expansion of their country's power.

Realistically, the short-term approach to protecting Chinese overseas workers' rights lies in initiating changes domestically in China. This includes pressing the Chinese government to shoulder more responsibility, to amend its domestic employment legislation, to expand its participation in international legal labour systems-as well as in global and regional institutions focussing on migrant workers-and to offer a series of feasible support channels, such as consular protection early-warning mechanisms and security institutes for overseas workers. Reinforcing the protection for the rights of Chinese overseas workers has not only added novel challenges and impetuses to China's domestic legislation on employment, but has also been linked to the success of the government's Belt and Road Initiative, as well as to the expansion of the country's clout in global governance.

What happened to Mr Dong, nevertheless, indicates that there is much more that China must do in this new era characterised by the global Chinese worker.

An earlier version of this essay was translated from Chinese into English by Nan Liu. 